\title{
Analysis of Media Literacy Levels of Palm Oil Farmers in Riau Province, Indonesia
}

\author{
Roza Yulida ${ }^{1}$, Rosnita ${ }^{1}$, Eri Sayamar ${ }^{1}$, Yeni Kusumawaty ${ }^{1} \&$ Yulia Andriani $^{1}$ \\ ${ }^{1}$ Department of Agribusiness, Faculty of Agriculture, Riau University, Indonesia \\ Correspondence: Roza Yulida, Department of Agribusiness, Faculty of Agriculture, Riau University, Indonesia. \\ E-mail: roza.yulida@lecturer.unri.ac.id
}

Received: July 1, 2019 Accepted: October 8, $2019 \quad$ Online Published: October 21, 2019

doi:10.5539/ass.v15n11p48

URL: https://doi.org/10.5539/ass.v15n11p48

\begin{abstract}
Oil palm plantations are a potential commodity of Riau Province and the highest contributor to palm oil production in Indonesia. The development of agricultural science and technology, which is disseminated through various media, is a source of information for farmers. However, the availability of information sources does not guarantee that farmers will benefit from the information. This is influenced by media literacy from these farmers. This research aimed at analyzing the media's literacy of oil palm farmers. The research was conducted in three districts with potential oil palm at Riau Province. They are Pelalawan District, Rokan Hilir District and Rokan Hulu District. The respondents of oil palm farmers were 185 farmers, which were selected by stratified random sampling. This research applied Likert Summated Rating Scale (LSRS) method. The results of this research are: The literacy level of oil palm farmers is in the medium level (average score of 1.72), while for three aspects which are technical skill and critical understanding are in the medium level and communication skill is basic level. Role of government and related parties are needed to help improve the literacy level of oil palm farmers. This is necessary so that the farmers together with extension workers, will be ready to face the challenge of the development of science and technology in the oil palm industry, by utilizing the development of information and communication technologies such as smartphones.
\end{abstract}

Keywords: media literacy, communication, oil palm farmer

\section{Introduction}

According to Mittal (2019), in the agricultural community cell phone use continues to increase. The results of the Mwakaje's research (2010) show that most farmers use information and communication technology to access information. The results of Chhaachhar's research (2014) on the use of information and communication technology such as the internet, mobile phone, radio and television, have been able to provide knowledge and information to farmers in developing their agriculture. According to Lamotey (2018), mobile phone technology used to access agricultural information can maximize the quality and quantity of agricultural production.

One of the supporting conditions for the development of agriculture is an agricultural extension. Therefore, the role of agricultural extension is very important for the development of farming communities. Media is one element of agricultural extension which is used as a medium for conveying messages, information, knowledge and technology to farmers. Two parties that are directly involved in the extension activities and in determining the success of communication are the extension workers and farmers. The extension workers convey the message and the farmers receive the message or vice versa. The results of Altalb's research (2015), stated that the importance of agricultural extension workers role in the technology transfer. The results of Ali's research (2018) show that farmers are still limited in getting the ability to use information and communication technology for farm management of extension workers. According to Schmidt (2012), it is important that all members of the society develop competencies related to media use, creation, and analysis in order to both participate in a democratic culture and compete in the modern workforce.

A person's perspective on media messages dictates how he responds to every message that comes to him and how he behaves. Individual competency is a person's ability to use the media. Some capabilities to utilize the media include the ability to use, produce, analyze, and communicate messages through media. Individual competency has two variables; personal competency and social competency. These two variables will illustrate the literacy level of the farmers in accessing, analyzing, and evaluating the meaning of the images, sounds, 
messages we face daily. They are also an important part of our contemporary culture, and to communicate competently with the private available media. In addition, media literacy also relates to all media, including television and film, radio and music recorders, print media, internet and other new digital communication technologies. As suggested by Monika et al. (2013), information and media literacy are accepted as indispensable in the modern world. Sramova (2014) defined media literacy as "the ability of an individual to understand how the mass media work, how they create and arrange their messages, and how these messages are then conveyed to their audiences".

Today, media literacy are often considered together with digital literacy, as they share several common elements: both involve competence in varied means of communication, and both digital literacy and media literacy involve the use of technology (whether high-tech, i.e. computers or low-tech, i.e. printed materials) in some forms. According to the American Library Association (2016), digital literacy is "the ability to use information and communication technologies to find, evaluate, create, and communicate information, requiring both cognitive and technical skills."

Also, according to the National Association for Media Literacy Education (2016), media literacy is "the ability to encode and decode the symbols transmitted via media and the ability to synthesize, analyze and produce mediated messages" (Dalton, 2017).

Media plays a vital role in improving farmers' productivity. Through the media, information and communication can be delivered well to farmers and provide new knowledge that will help the farmers to improve productivity. Media has a strong link to the success of counseling; in addition to agricultural extension activities by dealing with the limitations, including the limited number of extension workers, limitations on the target, such as the level of formal education of farmers varied, the limited facilities and limited learning time for farmers. The limitations need to be balanced by increasing the role and use of agricultural extension media. It is expected that through the agricultural extension media, farmers can increase the interaction with the environment so that the learning process will continue even if they are not dealing directly with the source of communication. According to Food and Agriculture Organization (FAO) (2013), in agricultural development, role of ICT/ICM (Information and Communication Technology/Information and Communication Management) is going to be significant in future initiatives for transforming agricultural research for development worldwide. Advances in ICT/ICM in the Asia-Pacific region reveals that more and more rural people are using community radio, mobile phones and the internet. In some contexts, farmers have used video through internet applications to gain advice on crops, animal husbandry, the threats posed by weather, pests and diseases, markets and prices and in the process enhance their access to and use of NARS (National Agricultural Research Systems) derived technology.

Indonesian plantation statistics for oil palm commodities in 2017 showed the largest land area $(2,400,485$ ha or $35 \%$ of Indonesia's total oil palm plantation area), the highest production amount $(9,071,275$ tons or $36 \%$ of national production), are in Riau Province. In Riau Province, 46\% (4,049,409 tons) of palm oil production came from smallholder plantations, with a land area of 1,341,397 ha (56\%) of the total area of oil palm plantations. Plantation subsectors, especially oil palm, have shown a significant impact on improving the socio-economic conditions of local communities (Directorate General of Estate Crops, 2017). Extension activities have contributed to assisting and fostering oil palm farmers, where one of the elements of extension that plays an important role is the extension media. The media literacy capability of extension workers and farmers will also determine the success of extension activities, including extension activities of oil palm plantations. Therefore, the purposes of this study are to: (1) Study the level of media literacy of plantation extension agents in Riau Province and (2) Assess the level of media literacy of oil palm farmers in Riau Province.

\section{Literature Review}

\subsection{Information and Communication Technology (ICT) in Agriculture Development}

FAO (2013) states that the use of ICT for agricultural and rural development has developed rapidly over the past decade in the Asia-Pacific region. The application of ICT in agricultural and rural development, including the use of hardware, software, applications in the form of digital content, management and use, institutional management and organizational structure related to variety of information, data and knowledge, has played a significant role.

Information dissemination and education to farmers in the agricultural sector in Indonesia is conducted by the Agricultural extension officers. Electronic media is very effective in disseminating information needed by farmers on time. The results show that cellular and internet can be a source of agricultural information needed by farmers. Agricultural extension officers have the role of helping to awaken and familiarize farmers to utilize modern information and communication technology and help farmers if they experience obstacles in their use. 
However, there may be many extension workers who lack of skills in the use of information and communication technology, therefore, extension workers need training in their positions as extension and capacity builder (Aldosari, 2017).

ICT is a driving force in developments and changes in all sectors, including agriculture. Great transformation in people's lives, especially in developing countries depending on the progress of information and communication technology. The development of information and communication technology has been able to overcome national and international barriers and transform the world into a global village, making information available to everyone, wherever and whenever needed (Gui, 2016).

The Farmers have a variety of information sources such as the internet, social media, and others. Most farmers use social media to look for agricultural information, but there are obstacles faced by farmers such as poor network, power outages, and high costs (Kipkurgat, Onyiego, \& Chemweina, 2016).

\subsection{Media Literacy}

Media literacy is a person's ability to search, process information, utilize and share information with others (Sramova, 2013). The research showed that media literacy was able to increase farmers' productivity, thus media literacy is important in agricultural development. Communication between farmers and extension workers can increase farmers' awareness of the development of agricultural information to improve productivity (Sokoya, 2014). According to Rayala (2017), "media literacy has traditionally meant the ability to access, analyze, evaluate and create media in a variety of forms. The ability to read and write gives people some power in their lives".

Media literacy is broadly defined as an individual's capacity to interpret autonomously and critically the flow, substance, value and consequence of media in variety of forms. There are two dimensions within media literacy: (1) individual competences (IC) and (2) environmental factors (EF). IC dividing into a further two dimensions of personal and social competences. These are separable also as (a) technical skill; (b) critical understanding; and (c) communication ability. EF is represented by five principle areas as (1) media education; (2) media literacy policy; (3) media industry; (4) civil society; and (5) the availability of media and information (European Commission, 2009).

The results of research on media literacy conducted by Potter and Thai (2016) indicated that the components often found in the concept of media literacy are knowledge, skills and behavior, and each component requires different gauges.

\section{Methodology}

This study was conducted in Riau Province, Indonesia, which was chosen based on the consideration that it is the area with the largest production of palm oil in Indonesia.

The research was conducted in three regency in Riau Province, namely Pelalawan Regency, Rokan Hilir Regency and Rokan Hulu Regency. To be able to represent all existing farmer groups, the research respondents were determined by stratified random sampling from all groups (a chairman, a secretary, a treasurer and two active members of group). So that the number of farmers taken as respondents from each group was five farmers, so the total number of respondents was 185 farmers. This number is considered sufficient, in accordance the opinion of Pandis (2015), that samples with a size of more than 30 will be normally distributed. According to Boddy (2016) qualitative research depends on the scientific paradigm in which research is conducted.

To measure the level of media literacy, farmers and oil palm extension workers in Riau Province the Likerts Summated Rating Scale (LSRS) was used where each choice of answers is given in a score of 1,2 and 3. After calculating the weight of each component of media literacy assessment, the next step was analyzing the results of the questionnaires and combining them with the weight of each component. The results of these calculations will determine the level of media literacy skills. The level of media literacy ability is divided into three categories, namely basic, medium and advanced.

Table 1. Media literacy category

\begin{tabular}{ccc}
\hline \multicolumn{3}{c}{ Perception rate of media literacy level } \\
\hline No. & Level & Scale Value Category \\
\hline 1 & Basic & $1,00-1,65$ \\
2 & Medium & $1,66-2,31$ \\
3 & Advance & $2,32-3,00$ \\
\hline
\end{tabular}


To examine the extent of literacy capacity of extension workers and oil palm farmers in Riau Province, the Likert Summated Rating Scale (LSRS) was used in which each choice of answers was scored. After knowing the weight of each component for media literacy assessment, calculation of questionnaire was conducted and combined with the weight of each component. The results of these calculations will further determine the level of media literacy capability. The level of media literacy ability was divided into three categories, namely basic, intermediate and advanced. The extension literacy and farmers' extension ability is presented in Table 2.

Table 2. Media literacy criteria and indicators

\begin{tabular}{lll}
\hline No. & Criteria & Indicators \\
\hline \multirow{3}{*}{ 1. Technical Skills } & a. Basic ability to use computer and internet \\
& b. Ability to use the media actively \\
& c. Ability to use the internet to search for information \\
& a. Have knowledge about media and media regulation \\
2. Critical Understanding & b. Ability to understand the content and function of media \\
& c. User behavior in using media \\
3. Communicative Abilities & a. Ability to communicate and build social relations through the media \\
& b. Ability to participate with the community through the media
\end{tabular}

Source: European Commission (2009)

\section{Results and Discussion}

The extent of literacy capacity of the extension media and farmers in Riau Province, and the ability to use, produce, analyze, and communicate messages through media were assessed from individual competency. Individual competency is a person's ability to utilize the media. The individual's competency to utilize the media has three variables. They are; technical skills, critical understanding, and communicative abilities.

Technical skills are the abilities and knowledge involved in using the media. Critical understanding is a cognitive ability in using the media such as the ability to understand, analyze, and evaluate media content. Communicative abilities are the abilities to build social relationships and participate in a community or environment through the media.

\section{Internal Characteristics of Farmers}

Internal characteristics are an important aspect of research, knowing the internal characteristics of the respondents can describe or give general description of the conditions and literacy capabilities of farmers.

Table 3. Internal characteristics of farmers

\begin{tabular}{cccc}
\hline No & Information & Total & Percentage \\
\hline $\mathbf{1}$ & Age (years-old) & & \\
& Productive (15-54 years old) & 163 & 88,11 \\
Not productive (>54) & 22 & 11,89 \\
$\mathbf{2}$ & Level of education & & \\
Elementary School & 34 & 18,38 \\
& Junior High School & 67 & 36,22 \\
& Senior High School & 83 & 44,86 \\
& Bachelor degree & 1 & 0,54 \\
$\mathbf{3}$ & Farming Experience (years) & & \\
& $1-15$ & 35 & 18,92 \\
& $>15-30$ & 138 & 74,59 \\
& $>30-45$ & 12 & 6.49 \\
$\mathbf{4}$ & Land Area (Hectares) & 180 & 97,30 \\
& $1-7$ & 1 & 0,54 \\
& $>7-14$ & 4 & 2,16 \\
$\mathbf{5}$ & $>14-21$ & & 10,27 \\
\hline
\end{tabular}




\begin{tabular}{lcc}
$3-4$ & 119 & 64,32 \\
$5-6$ & 47 & 25,41 \\
\hline
\end{tabular}

Source: 2019 processed data

The age of oil palm farmers is mostly in the productive age (ages 15 - 54 years), which are 163 farmers $(88.11 \%)$ and unproductive as many as 22 respondents $(11.89 \%)$. Farmers who are in productive age are expected to be easier to absorb information, innovation and technology provided by extension agents to increase knowledge.

The education level of the respondents of senior high school graduates are 83 people (44.86\%) and junior high school graduates are 67 people $(36.22 \%)$, and elementary school graduates are 34 people $(18.38 \%)$, and bachelor degree as many as one person $(0.54 \%)$. The results of Oladele's research (2015) show that the factor of education, the constraints on the use of tools, the use of information technology tools, are factors that influence information access.

Farming experience is one of the determinants of the success of a farmer in farming, the length of farming that is carried out will also add to their experience in efforts to increase their farming productivity. The longer the farmer runs the farming business that he manages, the more experience they will gain based on managed farming. The experience of oil palm farming are divided into three categories, namely farming experience in the range of 1-15 years as many as 35 people (18.92\%), farming experience of over $15-30$ years as many as 138 people (74.59\%) and farming experience above 30 - 45 years as many as 12 people $(6.49 \%)$.

One of the factors that greatly influences income is the area of agricultural land owned. The wider the agricultural land owned it will be directly proportional to income so that the possibility of additional income will be even greater. The area of dominant land ownership is in the range of 1-7 ha as many as 180 people $(97.30 \%)$ and farmers who own the land area of $>7-16$ ha as many as 1 person $(0.54 \%)$, and those who have land $>16-21$ ha as many as $4(2.16 \%)$ oil palm farmers.

Family dependence is the number of family members who are dependent on the head of the family consisting of wife, children and other family members who live in one house and eat from one kitchen. Every farmer have varies family dependents from one to the other. The dominant number of respondent families is in the group of 3-4 family dependents, namely 119 farmers (64.32\%). Meanwhile, family dependents of 5-6 as many as 47 farmers $(25.41 \%)$ and 19 other farmers $(10.27 \%)$ have family dependents of $1-2$ people. This shows that the number of dependents of oil palm farmers is classified as moderate. The number of dependents of this family has a large effect on the income and expense of farmer households, where the more the number of dependents on the farmer's family, the greater the costs incurred to meet household needs.

\section{External Characteristics of Farmers}

External characteristics are important aspects that come from the environment. To find out the external characteristics of farmers can be seen in the following table.

Table 4. External Characteristics of Farmers

\begin{tabular}{cccc}
\hline No. & Variable & Variable Category & Category \\
\hline 1. & Extension Intensity & 1,94 & Medium \\
2. & Accuracy of Channel Extension & 2,28 & Medium \\
3. & Total Resources & 2,29 & Medium \\
4. & Affordability to Access Information Sources & 2,28 & Medium \\
5. & Availability of Facilities Providers of telecommunications equipment & 2,51 & High \\
6. & Environmental support capacity & 2,56 & High \\
\hline
\end{tabular}

Agricultural extension has done well. On the intensity indicator of counseling with a score of 1.94 with the medium category, the agricultural instructor in providing counseling about oil palm cultivation 2 times a year.

Extension channels have several parts, namely in the form of communication between farmers and extension agents directly or utilizing tools such as mass media in extension activities. Table 4 shows that in terms of the accuracy of the extension channel the medium category was obtained with an average score of 2.29. This condition shows that oil palm farmers have been able to easily obtain information about oil palm extension from extension workers if extension activities are carried out directly. One example is counseling directly delivering counseling material for oil palm plantations with a lecture and also debriefing system.

Table 4 shows that the information source variable obtained by oil palm farmers on oil palm cultivation is in the 
medium category with an average score of 2.29. Amount of the latest information on the cultivation of oil palm plants received by farmers on average as much as 2 information, namely from extension agents and intermediary traders of their TBS (toke), information obtained by farmers in the form of material relating to fertilizers, pesticides and TBS prices. But there are also farmers who get information from other sources, such as smartphones and other farmers.

Table 4 states that the affordability variable accessing information sources for oil palm farmers has a score of 2.28 with a moderate category. Oil palm farmers can reach or access sources of information about oil palm farming activities and are also supported by their affordable accommodation on the internet, thereby facilitating communication by telephone.

Table 4 shows that the availability of telecommunications equipment media providers with a score of 2.51 with High category. This shows that farmers are already very easy to get telecommunication equipment providers or media sellers such as handpohones, computers, laptops, starter cards / internet packages, media services and accessories.

Environmental carrying capacity is a supporting factor in the use of media, namely, the availability of internet networks and so on in accessing information. Table 4 shows the variable carrying capacity of the environment to support the communication activities of oil palm farmers having a score of 2.56 in the High category. This explains that the environment has used a lot of media such as telephones to communicate, and has been supported with good networks.

\subsection{Level of Media Literacy Ability of Farmers}

Today media literacy counts as a necessary key skill for modern society. As new technologies and media are used more and more throughout social life, people need to develop more than just their Information Communication Technology (ICTs) skills; they need a broad digital awareness of the wider context in which technologies and media operate to wrap around these skills in order that they can participate in this increasingly digital world. Media literacy is characterized by the concept of "media competence" and is combined with all types of specific media-related activities (Park, 2017).

According to Fawole and Olajide (2012), farmers today are more aware of new ICTs such as mobile phone and internet compared to old technology such as fax machines and overhead projectors. However, it is important to overcome the most significant barriers for farmers to use ICTs which are the cost of techology, service failure, limited power supply, and low quality ICT products. The level of media literacy ability of oil palm farmers in Riau Province is presented in Table 5.

Table 5. The Level of Media Literacy Ability of Oil Palm Farmers in Riau Province, Indonesia

\begin{tabular}{ccc}
\hline Media Literacy & Score & Level \\
\hline Technical skills & 1.82 & Medium \\
Critical understanding & 1.80 & Medium \\
Communicative abilities & 1.56 & Basic \\
Total Score & 5.18 & Medium \\
Average Score & 1.72 & Medium \\
\hline
\end{tabular}

Based on Table 5, the level of media literacy capability of oil palm farmers in Riau Province is at a medium level with an average score of 1.72 . This shows that oil palm farmers are quite able to take advantage of the advances in media technology that are currently developing. It can be seen from the technical skills (medium level) and critical understanding (medium level) of oil palm farmers in using computer, the internet, and mobile phone, as well as the active use of the media. Although not widely used to search for information and build their oil palm farming. Communicative abilities of farmers to build social relations and participate in the community through media is still limited (basic level). Basically, farmers know the basic functions and purposes of using media such as the benefits of using computers, the internet and mobile phone, but less able to use and utilize these media to participate with communities in building relationships for the benefit of oil palm farming. Extension worker is one of the parties close to farmers, with extension activities. Farmers and extension worker can communicate and interact and teach farmers to use a variety of media well to improve the literacy skills of farmers, utilize the development of communication media science and technology in order to improve and develop oil palm farming. This result is consistent with Aldosari et al. (2017) who suggests that the extension officers may not have exposure to the modern ICT products and they may need training programs to make them familiar with the emerging technologies. 


\section{Farmers' media literacy skills}

Technical Skills is technical capabilities in using media. Critical Understanding is a cognitive ability in using media such as the ability to understand, analyze, and evaluate media content. Communicative is an ability to build social relationships and participate in the community through the media.

\subsection{The Farmer's Technical Skill Level}

Table 6. The level of media literacy skills of oil palm farmers at Technical skills in Riau Province

\begin{tabular}{|c|c|c|c|}
\hline No & description & average & Level \\
\hline \multirow[t]{3}{*}{1.} & The Technical ability to operate a computer and use the internet & 1.81 & medium \\
\hline & - Ability to operate computer & 1.81 & Medium \\
\hline & - Ability to operate or access internet & 1.82 & medium \\
\hline \multirow[t]{3}{*}{2.} & The Ability to use smartphone & 1.83 & medium \\
\hline & - Technical use of smartphone to communicate & 1.86 & Medium \\
\hline & - Technical use of smartphone to find information through Google and YouTube & 1.80 & medium \\
\hline \multirow[t]{8}{*}{3.} & Technical ability to use media actively & 1.81 & Medium \\
\hline & - $\quad$ Technical use of the internet actively & 1.82 & Medium \\
\hline & - $\quad$ Confidence in information obtained from the internet & 1.85 & Medium \\
\hline & - $\quad$ Technical use of social media actively & 1.66 & Medium \\
\hline & - $\quad$ Technical use ofyoutubeactively & 1.70 & Medium \\
\hline & - $\quad$ Technically communicate with extension agents actively & 2.48 & Edvanced \\
\hline & - $\quad$ Technical use of the official site of oil palm farming actively & 1.36 & Basic \\
\hline & Technical Skill & 1.82 & medium \\
\hline
\end{tabular}

Table 6 media literacy ability level of oil palm farmers in Riau Province in the Technical Skills is in the medium level with an average score of 1.82. Judging from the average score per indicator in Technical Skills that are already quite good, some farmers are limited to knowing how to use computers and also the internet. The ability of farmers to use computers is that some farmers know about computers such as turning on the computer, operating ( $\mathrm{ms}$ word, excel, and power point). Then in accessing the internet, farmers use the internet such as (google, facebook, youtube and whatsapp) to communicate and search for things on the internet. However, some oil palm farmers (who are generally old-age) do not yet know how to operate computers and techniques for searching information through the internet, so they are not yet active in seeking information through information and communication technology.

Most oil palm farmers have smartphones, which are used as tool to communicating and using social media. So how to use a smartphone such as for contacting other people like family, friends, and extension agent, farmers are able to use it. And the commonly used social media is WhatsApp and Facebook. Farmers also know how to find information on the internet and youtube on their smartphones. But there are still farmers who do not own a smartphone because the price is quite expensive, it is difficult to use and there are those who do not really need a smartphone, enough with existing cellphone. Even if they need information through the internet, usually the farmer asks for help from other family members such as children who have a smartphone to help them. Previous research (Allahriya et al., 2007) suggested that the user's skill is among the most important factors which influence the feasibility of the use of mobile phones as an educational medium in agricultural extension activities.

The technical ability of farmers to actively use the media is good enough. Where some farmers have been able to use the internet to find information. In obtaining information on the internet, farmers still choose information that they think is in accordance with what they are looking for, and sometimes the information can be obtained that does not apply to their daily lives or to the farmers' oil palm farming. For the use of social media, youtube and official sites, most farmers do not use it actively and some do not know the official website at all. In terms of communicating with farmer extension officers it is active (advanced category).

\subsection{The Farmers' Critical Understanding Ability Level}

For people in developing countries, the mobile phone is more accessible. There are still major gaps in terms of quality and affordability, but the majority of people in developing countries today have access to mobile phones. As companies are developing cheap models of smartphones, a growing number of people in developing countries are also able to access the internet via their mobile phones (Uimonen, 2012). 
Table 7. The level of literacy skills of oil palm farmers in a critical understanding in Riau Province

\begin{tabular}{|c|c|c|c|}
\hline No & Description & Average & Level \\
\hline \multirow[t]{6}{*}{1.} & The Knowledge of media usage & 1.82 & medium \\
\hline & - $\quad$ Level of knowledge using the internet & 1.89 & Medium \\
\hline & - $\quad$ Level of knowledge using social media & 1.76 & Medium \\
\hline & - $\quad$ Level of knowledge communicating with extension agents & 2.45 & Advance \\
\hline & - $\quad$ Level of knowledge using the oil palm farming official site & 1.31 & basic \\
\hline & - $\quad$ Level of knowledge using YouTube & 1.67 & medium \\
\hline \multirow[t]{6}{*}{2.} & The Ability to understand media content and functions & 1.92 & Medium \\
\hline & - $\quad$ Level of understanding of internet functions & 1.90 & Medium \\
\hline & - $\quad$ Level of understanding of social media functions & 1.79 & medium \\
\hline & - $\quad$ Level of understanding of youtube functions & 1.72 & medium \\
\hline & - $\quad$ Level of understanding of the function of extension agents & 2.64 & Advance \\
\hline & Level of understanding of the oil palm farming official site & 1.53 & Basic \\
\hline \multirow[t]{7}{*}{3.} & The User behavior in using media & 1.68 & Medium \\
\hline & - $\quad$ Level of frequency in using the internet & 1.84 & Medium \\
\hline & - $\quad$ Level of frequency in using social media & 1.71 & Medium \\
\hline & - $\quad$ Level of frequency in communicating with extension agents & 1.93 & Medium \\
\hline & - $\quad$ Level of frequency in using the oil palm farming official site & 1.33 & Basic \\
\hline & - $\quad$ Level of frequency in using youtube & 1.68 & Medium \\
\hline & Critical Understanding & 1.80 & Medium \\
\hline
\end{tabular}

Based on Table 7, the level of literacy skills of oil palm farmers in Riau Province on Critical Understanding is in the medium level with an average score of 1.80. This explains that farmers have knowledge of the media, and understanding media content and functions, and have used internet, social media, youtube, and contacting extension agents using mobile phones.

The knowledge of oil palm farmers about using media, such as the internet, social media (whatsApp and Facebook), and youtube is in the medium category. This illustrate, the oil palm farmers have knowledge in using smartphone media to communicate with other people, both using WhatsApp and Facebook. So does the case with knowledge in using media to search for information through the internet and youtube. But indeed there are still farmers who have not enough knowledge to use smartphones to communicate using social media and search for information through the internet and youtube. However, farmers do not have enough knowledge to access oil palm farming information through official sites which are recommended as the right source of information. For daily needs, oil palm farmers use mobile phones to communicate, including communicating with extension agents (advanced categories). The results of Avilesh's research (2017) show that extension are considered farmers as the most efficient method, followed by telephone and video calls. Mobile phone is the most important information and communication technology tool used by farmers.

The Understanding of oil palm farmers about the content and functions of internet media, social media (whatsApp and facebook), for some oil palm farmers is a media that is commonly used in everyday life. So they already have enough understanding of the content and functions of the media used. But for some farmers who are not used to it, some even do not know about the content and functions of the media. To communicate with extension agents using their mobile phones, almost all oil palm farmers already have sufficient understanding of their content and functions. The understanding of oil palm farmers is still in the basic category, on the content and functions of official sites to find information about oil palm farming, because farmers do not yet know it. The official palm oil site like: http://gapki.id, www.bpdp.or.id, www.iopri.org, http://www.infosawit.com.

Smartphones owned by some farmers are equipped with internet media, social media (WhatsApp and Facebook), and Youtube. So that for most oil palm farmers almost using the media WhatsApp and Facebook every day to communicate with family and friends. However, the media has not been used to communicate about oil palm farming through official sites, so the level of frequency of seeking information on oil palm farming through media is still a basic category. The results of the Borrelll's research (2018)in Inland Pacific Nortwest also point to the same thing, where farmers use the internet every day, but rarely access information related to farming. The level of frequency of farmers communicating with extension agents depends on the needs that need to be communicated. If there is information needed and problems regarding oil palm farming, the 
farmer will contact them.

\subsection{The Farmers' Communicative Ability Level}

The ability to communicate using the information media is one of the behaviors that will support the improvement of one's competence. The existence of communication technologies such as smartphones today helps to ease human life, including the improvements in science and technology. By being active in utilizing the media, the users may earn additional income. The results of Akanda and Rokhnuzzaman (2012) showed state that farmers need information for a variety of agricultural purposes, and they use different sources and media to access information.

Table 8. The level of media literacy skills of oil palm farmers on Communicative abilities in Riau Province

\begin{tabular}{|c|c|c|c|}
\hline No & Description & Average & Level \\
\hline \multirow[t]{6}{*}{1.} & The ability to communicate by building social relations through the media & 1.46 & basic \\
\hline & - Level of communication skills by building relationships through the internet & 1.41 & basic \\
\hline & - Level of communication skills by building relationships through the internet & 1.61 & basic \\
\hline & - Level of communication skills by building relationships through extension agents & 1.87 & medium \\
\hline & - Level of communication skills by building relationships through farming sites & 1.21 & basic \\
\hline & - Level of communication skills by building relationships through youtube & 1.21 & basic \\
\hline \multirow[t]{6}{*}{2.} & The ability to participate with the community through the media & 1.67 & Medium \\
\hline & - $\quad$ Level of ability to participate with the community through the internet & 1.61 & Basic \\
\hline & - $\quad$ Level of ability to participate with the community through the social media & 1.70 & medium \\
\hline & - $\quad$ Level of ability to participate with the community through the extension agents & 2.31 & medium \\
\hline & - $\quad$ Level of ability to participate with the community throughthe oil palm farming official site & 1.30 & basic \\
\hline & - $\quad$ Level of ability to participate with the community throughyoutube & 1.45 & basic \\
\hline \multirow[t]{7}{*}{3.} & The ability to produce and create media content & 1.50 & Basic \\
\hline & - $\quad$ Level of ability to produce and create media content through the internet & 1.62 & Basic \\
\hline & Level of ability to produce and create media content through the social media & 1.55 & basic \\
\hline & Level of ability to produce and create media content through the extension agents & 1.80 & medium \\
\hline & Level of ability to produce and create media content through the oil palm farming official site & 1.19 & Basic \\
\hline & Level of ability to produce and create media content through the youtube & 1.36 & Basic \\
\hline & Critical Understanding & 1.56 & Basic \\
\hline
\end{tabular}

Based on Table 8 the level of literacy ability of oil palm farmers in the Communicative abilities aspect is at the basic level with an average score is 1.61 . This explain that the ability to communicate by building the social relations of oil palm farmers in Riau Province through the media is still low, because farmers generally use the media (WhatsApp and Facebook) are limited to receiving and replying to messages, and contacting extension agents if there is a need. Farmers do not yet have the ability to create media to build relationships with other parties. The ability of farmers to use media such as cellphones / smartphones is generally taught by family members. There are also farmers who have not been able to use smartphone media, so if they want to communicate with family or friends, they are usually assisted by their children.

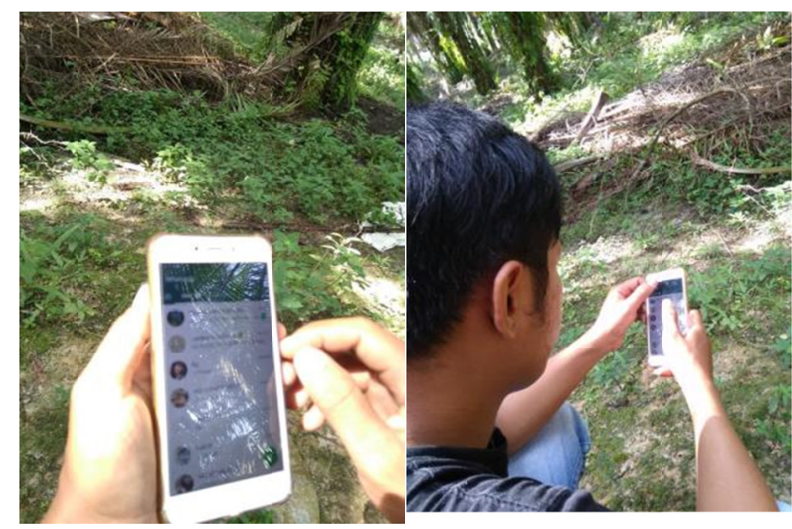

Figure 1. The Used of WhatsApp as media information 
Indicators of the ability to communicate by building social relations through the media is at the basic level. Farmers build relationships with other farmers using extension agents as media. Farmers have not been able to build relationships through the internet, the cellphones that are owned are only used to call and text farmer members. Farmers can use internet and social media (like whatsApp and Facebook), but don't know how to use the internet or social media to build relationships with others.

The ability of farmers to participate with the community through the media is quite good (medium level), even though it is only through social media and extension agents. The extension officers are indeed the media needed by oil palm farmers, to get information and help solve problems, because they can communicate directly (communication between individuals). Farmers only know the internet, do not participate, such as sending or receiving information on the internet, as well as the official oil palm farming site and youtube. Farmers only know the YouTube function to view videos but can't like, subscribe, comment and download videos or share videos.

Indicators of the ability to produce and create media content are at a basic level. The ability of farmers to produce and create media is only done through extension workers as media such as participating in counseling activities, always participating in training or coaching in villages through extension activities. Then for internet, social media, youtube, and official sites farmers do not yet have the ability to create media content to be able to share information and communicate with others. Sausa (2016) stated that the use of mobile phone for video distribution is very useful for extension and exchanging agricultural information, because farmers who cannot read can see and get information.

\section{Conclusions and Recommendations}

The media literacy ability level of palm oil farmers was examined from three aspects which were technical skill aspect, critical understanding, and communication abilities. The level of media literacy of oil palm farmers in Riau Province is at the medium level (score of 1.72). All the three aspects of technical skills are in the medium level with a score of 1.82 , critical aspects of understanding are also in the medium level with a score of 1.80 and aspects of communication abilities are in the basic level with a score of 1.56. Although the level of media literacy of farmers is at the medium level, it is still rarely used to find information and communicate about oil palm farming.

The role of government, universities and other related parties, with the extension officers will be able to improve the literacy of oil palm farmers to the advanced level. This is necessary so that the farmers together with extension workers, will be ready to face the challenge of the development of science and technology in the oil palm industry, by utilizing the development of information and communication technologies such as smartphones.

\section{Acknowledgements}

Acknowledgements to the Directorate of Research \& Community Service, Ministry of Research, Technology and Higher Education of the Republic of Indonesia.

\section{References}

Akanda, \& Roknuzzaman. (2012). Agricultural Information Literacy of Farmers in the Northern Region of Bangladesh. Journal Information and Knowledge Management, 2(6). Retrieved November 15, 2018, from https://iiste.org/Journals/index.php/IKM/article/view/2491

Aldosari, F., Al-Shunaifi, M. S., Ullah, M. U., Muddassir, M., \& Noor, M. A. (2017). Farmers' Perceptions Regarding the Use of Information and Communication Technology (ICT) in Khyber Pakhtunkhwa, Northern Pakistan. Journal of the Saudi Society of Agricultural Sciences. (In Press).

Ali, M., Norsida, M., Ismail, A. L., Farrah, M. M., \& Siti, Z. O. The Use of Information and Communication Technologies in Agricultural Risk Management by the Agricultural Extension Services in Malaysia. International Journal of Agriculture, Environment and Food Sciences.

Allahyaria, M. S., Atashi, M. R., \& Dunn, E. S. (2007). Feasibility of Using Mobile Phones as an Educational Medium in Agricultural Extension Services in Guilan Province, Iran. Journal of Agricultural \& Food Information, 1-12.

Altalb, A. A. T., Tadeusz, F., \& Piotr, S. (2015). The Role of Agricultural Extension in the Transfer and Adoption of Agricultural Technologies. Asian Journal of Agriculture and Food Sciences, 3(5).

Avilesh, J., Hardowar, S., \& Ruggoo, A. (2017). Accessibility and Relevance of Extension Methods and Information and Communication Technologies among Farmers in Mauritius. International Journal of 
Agricultural Extension and Rural Development Studies, 4(1), 31-43. Published by European Centre for Research Training and Development UK.

Boddy, C. R (2016). Sample size for qualitative research. Qualitative Market Research: An International Journal, 19(4), 426 -432. https://doi.org/10.1108/QMR-06-2016-0053

Borrelll, et al. (2018). Farmers' Trust in Sources of Production and Climate Information and Their Use of Technology. Journal of Extension, 56(3).

Chhachhar, et al. (2014). Impact of Information and Communication Technologies in Agriculture Development. Journal of Basic and Applied Scientific Research, 4(1), 281-288.

Dalton, E. (2017). Beyond Universal Design for Learning: Guiding Principles to Reduce Barriers to Digital \& Media Literacy Competence. Journal of Media Literacy Education 9(2), 17-29. https://doi.org/10.23860/JMLE-2019-09-02-02

Direktorat Jendral Perkebunan. (2016). The Crop Estate Statistic of Indonesia Palm Oil 2015-2017. Jakarta.

European Commission Directorate General Information Society and Media Literacy Unit. (2009). Final Report Study on Assessment Criteria for Media Literacy Level. A comprehensive view of the concept of media literacy and an understanding of how media literacy levels in Europe should be assessed. Brussel, October 2009. Retrieved from http://ec.europa.eu/assets/eac/culture/library/studies/literacy-criteria-report_en.pdf

Fawole, O. P., \& Olajide, B. R. (2012). Awareness and Use of Information Communication Technologies by Farmersin Oyo State, Nigeria. Journal of Agricultural \& Food Information, 13, 326-337. https://doi.org/10.1080/10496505.2012.717003

Food and Agriculture Organization (FAO). (2013). Information and communication technologies for sustainable agriculture Indicator from Asia and the Pacific. Food and Agriculture Organization (FAO) of the United Nations.Regional Office for Asia and the Pacific. Bangkok, 2017. RAP PUBLICATION.

Food and Agriculture Organization (FAO). (2017). Success stories on information and communication technologies for agriculture and rural development. Food and Agriculture Organization (FAO) of the United Nations.Regional Office for Asia and the Pacific. Bangkok. Retrieved from http://www.fao.org/3/a-i4622e.pdf

Gui, M., Fasoli, M., \& Carradore, R. (2017). "Digital Well-Being": Developing a New Theoretical Tool for Media Literacy Research. Italian Journal of Sociology of Education, 9(1), 155-173.

Joobrachi, T. N., Hassan, M. S., \& Osman, M. N. (2013). Relationship between Internet Usage and Positive Youth Development in Malaysia. Malaysia: SEARCH Journal, 5(2), 27-64.

Levine, P. (2015). Media Literacy for the 21st Century. A Response to "The Need for Media Education in Democratic Education". Democracy and Education, 23(1), Article 15. Retrieved from https://democracyeducationjournal.org/home/vol23/iss1/15

Kipkurgat, O., \& Chemweina. (2016). Impact of Social Media on Agricultural Extension in Kenya: A Case of Kesses District. International Journal of Agricultural Extension and Rural Development Studies, 3(1), 30-36. Published by European Centre for Research Training and Development UK.

Mittal, S., \& Mamta, M. (2012). How Mobile Phones Contribute to Growth of Small Farmers Evidence from India. Quarterly Journal of International Agriculture, 51(3), 227-244. International Maize and Wheat Improvement Center (CIMMYT), New Delhi, India.

Mgbakor, M., Iyobor, O., \& Okezie, U. P. (2013). Contributions of Mass Media to the Development of Agricultural Extension in Ika North East L.G.A of Delta State, Nigeria. Academic Journal of Plant Sciences, 6(3), 127-133.

Mwakaje, A. G. (2010). Information and Communication Technology for Rural Farmers Market Access in Tanzania. Journal of Information Technology Impact, 10(2), 111-128.

Oladele, O. I. (2015). Effect of Information Communication Technology (ICT) on Agricultural Information Access among Extension Officers in North West ProvinceSouth Africa. South Africa Journal Agricultural Extention, 43(2), 30-41. https://doi.org/10.17159/2413-3221/2015/v43n2a344

Park, J. (2017). Media Literacy, Media Competence and Media Policy in the Digital Age. Hawaii University International Conferences Arts, Humanities, Social Sciences \& Education, January 3-6, Ala Moana Hotel, Honolulu, Hawaii.

Retrieved

from 
https://huichawaii.org/wp-content/uploads/2017/02/Park-Jooyeun-2017-AHSE-HUIC.pdf

Potter, \& Thai. (2016). Conceptual Challenges in Designing Measures for Media Literacy Studies. International Journal of Media and Information Literacy, 1(1), 27-42. https://doi.org/10.13187/ijmil.2016.1.27

Pandis, N. (2015). Analysis of Variance. American Journal of Orthodontics and Dentofacial Orthopedics, 147(4), 517-519. https://doi.org/10.1016/j.ajodo.2015.01.009

Agricultural Extension Center, Agricultural Extension Agency and Human Resource Development, Ministry of Agriculture. (2011). Implementation Guidelines of Farmer Group Evaluation. Retrieved from http://cybex.pertanian.go.id/files/isi.pdf

Rayala, M. (2017). Fostering Agency through Media Literacy. The Journal of Media Literacy, 6(1\&2). Retrieved September 20, 2018, from http:/www.aml.ca/wp- content/uploads/2017/03/JMLVo.64No.12-2017.pdf

Ruben, R., Slingerland, M., \& Nijhoff, H. (Eds.). (2006). Agro-food chains and networks fordevelopment (pp. 1-25). Springer.

Schmidt, H. (2012). Media Literacy Education at the University Level. The Journal of Effective Teaching, 12(1), 64-77.

Sokoya, A. A., Alabi, A. O., \& Fagbola, B. O. (2014). Farmers Information Literacy and Awareness towards Agricultural Produce and Food Security: FADAMA III programs in OsunState Nigeria. Retrieved from http://library.ifla.org/1001/1/140-sokoya-en.pdf

Sousa, F., Gian N., \& Robert, H. (2016). Information technologies as a tool for agricultural extension and farmerto-farmer exchange: Mobile-phone video use in Mali and Burkina Faso. International Journal of Education and Development using Information and Communication Technology (IJEDICT), 12(3), 19-36.

Sramova, B. (2014). Media literacy and Marketing Consumerism Focused on Children. Procedia Social and Behavioral Sciences, 141, 1025-1030. https://doi.org/10.1016/j.sbspro.2014.05.172

Thakur, C., \& Katoch. (2018). WhatsApp Model for Farmer Led Extension: Linking Actors and Generating Localized Information for Farmer. Asian Journal of Agriculture Extension, Economics \& Sociology, 26(4), 1-8. https://doi.org/10.9734/AJAEES/2018/43582

Uimonen, P. (2012). Social and Mobile Media in ICT4D. Social Media in Development Cooperation. Orecomm at Almo University and Roskilde University. Retrieved from http://orecomm.net/wp-content/uploads/2012/04/SocialMediaOrecomm2011.pdf

Wegand, M., Zylka, J., \& Müller, W. (2013). Media Competencies in the Context of Visually Impaired People. In S. Kurbanoğlu et al. (Eds.), European Conference on Information Literacy (pp. 190-197). Springer International Publishing Switzerland. https://doi.org/10.1007/978-3-319-03919-0_24

\section{Copyrights}

Copyright for this article is retained by the author(s), with first publication rights granted to the journal.

This is an open-access article distributed under the terms and conditions of the Creative Commons Attribution license (http://creativecommons.org/licenses/by/4.0/). 